\title{
Çokkültürlülük Kavramı ve Anlamın Çokluğu
}

\author{
Ömer Say*
}

İstanbul Medeniyet Üniversitesi, Edebiyat Fakültesi, Sosyoloji Bölümü, İstanbul

\section{Öz}

1970'lerden itibaren Kanada ve Avustralya çokkültürlülük politikasını benimsemişlerdir ve o zamandan beri çokkültürlülük kavramı gittikçe daha çok tartışılır olmuştur. Çokkültürlülük nispeten yeni bir kavramdır ve buradaki 'kültür' esas itibarlyla farkl topluluklara gönderme yapar. Bu yönüyle de politik bir kavramdır. Yirminci yüzyılın ikinci yarısında Batılı ülkelere gerçekleşen göçler nedeniyle oluşan kültürel topluluklar da, bu çokkültürlülük politikası içinde tartışılmaya başlanmıştır. Kavramsal düzeyde çokkültürlülük farklılı̆̆ın bir veri olarak kabul edildiği bir yaklaşım biçimi olarak ortaya çıkmıştır. Farklllıklara vurgu yapan çokkültürlülük politikası yirminci yüzyılda gelişen düşünce akımlarıla bazı paralellikler göstermektedir. Özellikle tanım ve anlam konusunda çoklu bakış açısı tartışmanın en önemli konusunu oluşturmaktadır. Anlamın çoklu oluşu da bir kültürün ya da grubun kendini tanımlaması ile ilişkili olarak farklılıklara düşünsel bir dayanak kurmaktadır. İdealizme ve nedenselliğge karşıt olarak geliştirilen anlam, çokluğun temelinde yer almaktadır. Ancak bu çokluk herhangi bir kökene bağlanmayan çokluk olarak dikkat çekmektedir. Bu haliyle de çokkültürlülük, çoklukla arasındaki ilişkide olduğu gibi farllıklar üzerinden kendine bir varlık alanı bularak belirmektedir.

Anahtar Kelimeler: Çokkültürlülük, Göç, Anlam, Farklllık, Çokluk.

\section{Concept of Multiculturalism and Multiplicity of Sense}

\section{Abstract}

As of 1970, Canada and Australia have adopted multicultural politics and the concept since then has been a disputed one. Multiculturalism is a relatively new concept and culture in it refers to different communities, which makes it a political term. In the second half of twentieth century cultural communities that have emerged due to immigration to western countries have also become an issue in multiculturalism debates. As a concept multiculturalism implies differences given in a society. Multiculturalist approaches has parallelism with some thoughts emerging in twentieth century. Especially multiple perspectives on definition and sense are most important views. Multiplicity in sense based on multiplicity forms intellectual platform for identifying a cultural group. Within this context sense opposes idealism and determinism. But that kind of multiplicity related with multiculturalism doesn't adhere to a root. Relations between multiplicity and multiculturalism from this point of view give way to difference in the realm of existing.

Keywords: Multiculturalism, Immigration, Sense, Difference, Multiplicity

\section{Gíriş}

Giddens ve Sutton, modern dünyada yaşanan göçlerin, dört modelle tanımlandıklarını belirtmektedirler. Onlara göre bu göçlerden birincisi 'klasik model'dir. Bu modelde Kanada, Amerika Birleşik Devletleri ve Avustralya gibi göçmen ülkeleri olarak gelişen devletlere yaşanan göçler değerlendirmeye alınmaktadır. Zikredilen ülkelere yeni gelen göçmenler genellikle vatandaşlık hakkı ile göçe teşvik edilmişlerdir. İkinci model 'kolonyal model'dir. Fransa ve Birleşik Krallık 
gibi ülkeler bu model içinde değerlendirilir. Hindistan, Jamaika gibi sömürge ülkelerden İkinci Dünya Savaşı sonrasında büyük sayıda göçmenlerin Fransa ve İngiltere gibi ülkelere yerleşimini kapsamaktadır. Üçüncü model Almanya, İsviçre ve Belçika gibi ülkelerin uyguladığı 'misafir işçiler modeli'dir. Bu model, belli düzenlemeler yoluyla göçmenlerin emek piyasası için kabul edilişini nitelendirmektedir. Sonuncu model ise 'illegal biçimler' başlı̆̆ı ile adlandırılmaktadır. $\mathrm{Bu}$ adlandırma ile de göçmenlerin gizli olarak ev sahibi ülkeye girişleri ifade edilmektedir. Amerika Birleşik Devletleri içindeki kaçak Meksikalılar bu gruba girmektedir (Giddens ve Sutton, 2013: 701).

Göçlerin farklı türde gerçekleşmiş olması ülkelerin göçlere ve göçmen sorunlarına farklı yaklaşımlarını doğurmuştur. Bunun yanı sıra göç kaynaklı sorunlara çözüm arayışlarının da farklılığı ayrı bir bakış açısı çokluğunu ortaya çıkarmıştır. Bu bağlamda II. Dünya Savaşı sonrası bir politik yönelim olarak ortaya çıkan çokkültürlülük, sanayileşme ilişkilerinin doğurduğu göç dalgaları sonucunda özellikle Batılı ülkelerde iyiden iyiye artan kültürel farklılıklara vurguyu güçlendirmiştir. Hatta yirminci yüzyılın ikinci yarısında işçi ihtiyacı nedeniyle dışarıdan göçmen kabul eden Kanada, Avustralya ve ABD gibi ülkeler genel itibarla çokkültürlülükle anılmaktadırlar. ABD resmi olarak çokkültürlü bir politika izlediğini belirtmemiştir ama diğer iki devlet resmi olarak çokkültürlülük politikasını benimsediklerini beyan etmişlerdir. Çokkültürlülük politikaları çerçevesinde de bu kültürel farklılar çeşitli bakış açıları altında ele alınmıştır.

\section{Çokkültürlük Politikasında İlk Örneklerin Uygulanış Serüveni}

Doytcheva, Glazer'e atıf yaparak 1970-1980 yılları arasında, başlığında çokkültürlülük geçen tüm kitapların Kanada ve Avustralya'da basılmış olduğunu söyler (Doytcheva, 2009: 15). Bunda tabi ki 1971 yılında Kanada'nın, 1974 yılında da Avustralya'nın çokkültürlülük politikasını benimsemiş olmaları, asıl önemi taşımaktadır. Cleyne ve Jupp da çokkültürlülügün yaklaşı olarak 1970 'ten bu yana Avrupa, Kuzey Amerika ve Avustralasya'daki farklı demokrasilerde tartışıldığını belirtmektedir. Onlara göre kavram, bu tartışma içinde aslen liberal demokrasinin temelleri üzerine bir politik sistemi referans olarak almaktadır (Jupp ve Clyne, 2011: XIII). Dahası bu tartışmanın sadece siyaset alanında kalmadığı akademik çalışmalarda da önemli bir yoğunlukla görülmeye başlandığı bilinmektedir. Fakat daha da önemlisi çokkültürlülük kavramı kuramsal düzeyde ona ilişkin farklı perspektiflerden yaklaşımların geliştirildiği bir alan haline gelmiştir.

Heywood da modern toplumdaki kimlikle ilgili farklılıkların altını çizen ve böylece 'farklılık siyaseti' üzerine yoğunlaşan bir kavram olarak çokkültürlülügüun 1960'lardan beri yükselmeye başlayarak hem tasvir edici ve hem de normatif olarak kullanıldığını belirtmektedir. Heywood, tasvir edici bir terim olarak kavramın, bir toplum içindeki inançları ve pratikleri farklı iki veya daha fazla grubun varlığından hareketle görülen kültürel çeşitliliği ifade ettiğini, normatif bir terim olarak ise farklı grupların saygı ve kabul görme hakkı veya ahlaki ve kültürel çeşitliliğin pozitif onayını ima ettiğini öne sürmektedir (Heywood, 2007: 172-173). 
$\mathrm{Bu}$ durumda çokkültürlülük kavramı içinde iki şey belirgin olarak öne çıkmaktadır: Birincisi çokkültürlülük yirminci yüzyılın ikinci yarısında tartışılmaya başlanmıştır. İkincisi de içinde geçen kültür kavramı, bizzat kavramın kelime anlamından ziyade onun diğer topluluklarla birlikte yaşayan farklı bir toplulukla anılması gereğini ya da şartını da beraberinde taşımaktadır. Çokkültürlülük içindeki kültür, bir grubun ya da topluluğun kendini farklılık içinde ifade etmesiyle anlaşılmaktadır. Burası önemlidir zira Bryson'un belirttiği gibi çokkültürlülüğün ele alınışı çoğunlukla kavramın tanımlanmasını içermez. Tanımın muğlak kalmasında birçok neden vardır. Muğlaklıktaki asıl sebep onun anlamının çok açık olmamasından kaynaklanmaktadır. Fakat yine de onun en genel anlamı değişik kültürlerin birlikte varlık bulmalarını ifade etmektedir (Bryson, 2005: 27). Bu yönüyle de kavram, her şeyden önce siyasal bir nitelemedir.

İlk olarak çokkültürlülügün bir politika olarak benimsendiği Kanada'da kavrama duyulan ihtiyacın Kanada'daki on eyaletten biri olan Quebecliler ile diğer dokuz eyaletin yönetimi arasındaki tartışmalardan doğduğu söylenebilir. Doytcheva'nın belirttiği haliyle Ülkede İngiliz Kanadalıların Fransız Kanadalılardan daha etkin olmaları üzerine 196011 yıllardan itibaren Fransız Kanadalılar arasında özerklik söylemleri görülmeye başlamıştır. Bu söylemler karşısında Kanada Federal Hükümeti tarafından önce, 1969 yılında Fransızların işe alınmasını kolaylaştıran bir uygulama olarak iki dillilik ilan edilmiştir. Ancak ülke içindeki milliyetçilik talepleri dinmemiştir. Bu taleplere bir cevap olarak federal hükümet 1971'de çokkültürlülük politikasını uygulamaya koymuştur. Bu çokkültürlülük siyaseti ile hedef, aynı statüde bireylerden oluşan yeni bir Kanadalı kimliğini teşvik etmektir (Doytcheva, 2009: 37-38). $\mathrm{Bu}$ gelişmeler de göstermektedir ki Kanada'daki çokkültürlülük politikasında asıl amaç ülkenin bütünlüğünü korumak ve ülke içindeki farklı siyasal eğilimlerin önüne geçmektir (Say, 2013: 177-182).

Avustralya'da da çokkültürlülügün politik bir tercih olarak yer almasındaki serüveni tarihsel gelişimi itibarıyla özet olarak şu şekilde ifade etmek mümkündür: Aslında ülke, II. Dünya Savaşına kadar zaten baskın şekilde çoğunluk olarak Büyük Britanya'dan ve İrlanda'dan gelen göçmenlerin yerleşim bölgesidir. Fakat özellikle 1945'ten sonra hükümetin de aktif olarak Avustralya'ya İngilizce konuşmayan ülkelerden geniş kapsamlı göçü desteklemesi sonucunda hızlı bir nüfus artışı yaşanmıştır. II. Dünya Savaşı sonunda, 1947'de, nüfus 7.6 milyonken 1979 yılında bu rakamın iki katına çıktığı bilinmektedir (Roach ve Alwis v.d. 1999: 23). Bu gelişme ile birlikte sadece nüfusun iki katına çıkmış olduğunu söylemek yeterli olmaz. Çünkü bir yandan da ülke içinde etnik çeşitlenme gerçekleşmiştir.

Kaldı ki 26 Ocak 1949'da yürürlüğe giren '1948 Milliyet ve Vatandaşlık Kanunu' sonrasında (1996'ya kadar) 3.1 milyon denizaşırı doğumlu kişi vatandaşlık için başvurmuş ve Avustralya vatandaşı olmuştur (Roach ve Alwis v.d. 1999: 24). 1947'de nüfusun 7.6 milyon olduğu dikkate alındığında vatandaşlık başvurusunda bulunan ve kabul alan 3.1 milyon kişilik nüfusun önemli bir oran teşkil ettiği görülecektir. Dolayısıyla etnik çeşitlenme açısından önemli bir oran kayda geçmiş olmaktadır. 
Demek oluyor ki Avustralya'da çokkültürlülük politikası, hızla geliştirilen göç politikası eliyle ülke nüfusunun çeşitlenmesine bağlı olarak oluşmuştur. Bu durumda şunu açık olarak belirtmekte fayda vardır ki II. Dünya Savaşı sonrasında Avustralya'da programlı bir şekilde göç politikasının uygulanması sonucunda çokkültürlülük politikası için bir gereklilik olan farklı kültürel grupların varlığı sağlanır olmuştur (Say, 2013: 182-188).

\section{Kuramsal Açıdan Çokkültürlülük: Üç Örnek}

Yirminci yüzyıl boyunca yaşanan gelişmeler karşısında, Kanada ve Avustralya örneklerinde görüldüğ̈ haliyle, kimi devletlerin çokkültürlü uygulamalara yönelirken aslında ülke içindeki farklılıkları siyasal bir anlam ifade etmeyen bir hayat tarzı içindeki gelenekler ve inançlar çerçevesinde açıklamaya çalıştıkları görülmektedir. Çokkültürlülük kuramları da bu gelişmenin bir ürünü olarak, modern devletlerin yasal bütünlüğü çerçevesinde kültürel farklılıkları yeniden yorumlayan yaklaşımlar olarak ortaya çıkmıştır. Bu siyasal bütünlük içinde kültürel farklılıkların teorik olarak açıklanabilmesi açısından çokkültürlülük kuramları hakkında genel bir bakış açısının ortaya konması önem taşımaktadır. Ancak çokkültürlülük tartışmalarının ve konu hakkındaki düşüncelerin tamamı üzerinde durmanın zorluğu nedeniyle bu çalışma içinde kuramsal yaklaşımlarıyla en çok tanınan kuramcılardan Kymlicka, Taylor ve Parekh'in görüşlerine özet olarak yer verilecektir.

Will Kymlicka, 1980'lerin ortalarına kadar çokkültürlülükle ilgili çalışmaların azlığını, bu alanda çalışan siyaset kuramcısının bir elin parmaklarını geçmeyecek kadar olduğunu söyleyerek belirtir. 1990 sonrasında ise tartışma büyümüştür ve bu nedenle terimleri de değişmiştir. Ona göre Batılı demokrasilerde çokkültürlülük üzerine beş tür etno-kültürel gruptan söz edilebilmektedir (Kymlicka, 2006: 465-466). Bu gruplara o, çokkültürlülüğün beş modeli demektedir. Bunlardan birincisi ‘ulusal azınlıklar'dır. Bu gruptakiler ülke içi azınlıklar ve yerli halklar olmak üzere ikiye ayrılır. Ülke içi azınlıklar bir devlete sahip olmayan ancak geçmişte bir devlete sahip olmuş ya da kurmaya çalışmış topluluklardır. Yerli halklar ise geleneksel olarak sahip oldukları topraklar yeni yerleşimcilerle işgal edilmiş ve zorla ya da anlaşmalarla ellerinden alınmış gruplardır. Çokkültürlülüğün ikinci modeli, 'göçmen gruplar'dır. Göçmenler belirli koşulları yerine getirmek suretiyle vatandaşlık hakkı tanımayı içeren bir politika içinde göç etmiş insanlardır. ABD, Kanada ve Avustralya gibi ülkelerin göçmenliği düzenlemeleri sonucunda buralara göç etmiş kişiler bu gruba dâhil edilmektedir. Onlara genel olarak toplumsal kültüre entegre olmayı kabul etmiş kişiler olarak bakılmaktadır. Üçüncü modelde 'tecrit edici etno-dinsel gruplar' yer almaktadır. Bu gruptakilere sivil topluma katılmaktan kaçınan Hutteritler, Amishler ya da Hasidik Yahudiler örnek gösterilmektedirler. Toplumun ve siyasetin yozlaşmış olduğunu düşünen bu gruplar bilinçli olarak askerlik benzeri çeşitli yasalardan muafiyet istemektedirler. Dördüncü modelde 'metikler' yer almaktadır. Bunlar ise ülkeye kaçak gelen ve bu nedenle her an sınır dışı edilme tehlikesi altında olan kişilerdir. Ancak gelişmeler göstermiştir ki bu kişiler yaşamlarını kaçak olarak bulundukları ülkelerde bir şekilde sürdürmektedirler. Son model ise 'Afrikalı-Amerikalılar'dır. Bu gruptakiler köle olarak zorla bir ülkeye getirilmiş ve kendi dillerini dahi unutmuş olan ama bir 
yandan da kültürel kurumlarla bütünleşmeleri de engellenmiş kişilerdir. Kymlicka'ya göre tüm bu grupların varlığıyla Batılı demokrasiler, güçlü azınlık hakları ile birleşmiş ve sınırlanmış güçlü ulus oluşturma biçimlerinden oluşan karmaşık bir paket görünümündedir. Ona göre liberal bir çokkültürlülük kuramının karşı karşıya olduğu en büyük işlerden biri etno-kültürel adaletin koşullarını anlamak ve eklemlemektir (Kymlicka, 2006: 483-508).

Taylor'a1 göre "kimliğimizi her zaman, önemli saydığımız öbür kişilerin bizde görmek istedikleri şeylerle diyalog içinde, bazen de çatışma içinde tanımlarız" (Taylor, 2010: 53). Dolayısıyla Taylor için kimlik zaten ister çatışma ister diyalog içinde olsun başkalarından bağımsız olarak kurulmamaktadır. Başkalarıyla birlikte kurulan kimlik sürecinde gerekli olan şey de ona göre eşit haysiyet politikasıdır. "Eşit haysiyet politikasıyla yerleştirilen şeyin, evrensel açıdan aynı şey, özdeş bir haklar ve bağışıklıklar paketi olması gerekir; farklılıklar politikasıyla kabul etmemiz istenen şeyse, şu bireyin ya da grubun kimliği, onları başkalarından farklı kılan ayırıcı özellikleridir." (Taylor, 2010: 59). Bu bağlamda başkalarıyla kuracağımız ilişkinin bir toplum içinde karşılıklı olarak eşit derecede tanınmışlıkla açıklanması gerekmektedir:

Bir yanda, eşit değerlerin tanınması yolunda sahici olmayan, hegemonyacı bir taleple, öte yandan kendini etnik merkezli ölçütlere hapsetme arasında bir şeyin bulunması gerekir. Başka kültürler vardır; bizler de hem dünya ölçeğinde, hem de tek tek her toplumun içinde bu kültürlerle karışmış olarak yaşamak zorundayız (Taylor, 2010: 92).

Parekh'e göre ise çokkültürlülük ne sadece politik bir doktrin ne de insan ve dünya için bir felsefi teoridir. O sadece perspektiftir. Çokkültürlülügün üç görünümü vardır: Birincisi, insan, kültürel olarak hayatını ve sosyal ilişkilerini organize eden ve ona kültürel olarak bir kimlik yükleyen yapılandırılmış bir dünyada büyümektedir. $\mathrm{Bu}$, kişinin kültürü tarafından belirlendiği anlamına gelmez fakat derinden biçimlendiği anlamını taşır. İkincisi, farklı kültürler farklı anlam sistemlerini temsil ederler. Her biri, sınırlı insan kapasitesini kavrayabileceği için insan varlığının bütünlüğünden sadece bir parçayı yakalayabilir. Bu da kişinin kendi kültürü ile iyi hayatı yakalayamayacağı anlamına gelmez. Daha ziyade hiçbir kültürün değersiz olmadığı anlamına gelir. Hiçbir kültür mükemmel değildir ve diğerleri üzerine kendini empoze etme hakkına sahip değildir. Her bir kültür, sınırlı olduğundan birbirleriyle karşılıklı ilişki de faydalı ve düşünce ufuklarını genişletici olacaktır. Üçüncüsü, ilkel kültürlerin çoğu dışında bütün topluluklar çoğuldur. Kültürler bilinçli ya da bilinçsiz olarak diğerleriyle etkileşim içinde gelişirler ve orijinleri ve oluşumları bakımından en azından kısmen çokkültürlüdürler (Parekh, 2000: 336-337).

Her üç düşünürün da yaklaşımı farklı kültürlere sahip insanların karşılıklı olarak birbirleriyle ilişki içinde oldukları fikrinden hareket etmektedir. Üç yaklaşım da bir toplumun homojen sayılamayacağı üzerinde birleşmektedir. Toplumların homojen olup olmadıklarına ilişkin yaklaşımlarını belirleyen bakış açılarını da Batılı ülkelerdeki farklı ırk, ulus, din ve diğer etnik grupların varlı̆̆

\footnotetext{
${ }^{1}$ Charles Taylor'un, çokkültürlülük konusundaki görüşleri daha geniş olarak yazarın "21. Yüzyılda Ulus Çokkültürlülük ve Etnisite" adlı kitabında yer almaktadır. Detaylı bilgi için bkz. Ömer Say, 21. Yüzyılda Ulus Çokkültürlülük ve Etnisite, Kaknüs Yayınları, İstanbul, 2013, s. 150-154.
} 
ülkelerin çoğunun yaşadıkları göç konusu aslında onların bakış açılarının temelinde önemli bir yer tutmaktadır ama yine de farklı grupların farklılıklarına yapılan vurgu bir veri olarak hazır şekilde kabul edilmektedir.

Bu düşünce biçiminin yukarıdaki üç düşünürde mevcut olduğu aşikârdır. Her üç düşünürde de kültürel farklılıklar bir veri olarak kabul edilmektedir. Yaşam pratiklerinden elde edilen bu farklılıkların kabulünde bir nedensellik ilişkisi de sorgulanmamaktadır. Gerçekte farkı bir neden ile açıklamak farklılığı minimize edecek bir düşünce biçiminde ilerlemeyi doğurabilmektedir. Zaten nedensellik belirli ilkeleri beraberinde taşımaktadır. Çünkü sabit durumlar ve ölçütler üzerinden yol almayı gerektirmektedir. Bu durum, sonuçta bir ölçütü merkeze alarak onun yasalaşmasını doğurmaktadır.

Nedenselliğin temele alındığı bir bakış açısına modern çağda oldukça sık başvurulmuş ve nedensellik bağıyla kesin doğrulara dayanan bir düşünce biçimi yaygın olarak kullanılmıştır. Nedensellik özellikle pozitivizmin beslenme kaynaklarından biri olarak da görülebilir. Fakat aynı zamanda nedensellik, Sokrates'inde üzerinde durduğu gibi ahlak ve erdem gibi konularda da ana damarı oluşturmaktadır. Zira Sokrates'in söylediği haliyle, hiç kimsenin bilerek kötülük yapmayacağı ve kötü insanların da daha çok hasta varlıklar oldukları görüşü çerçevesinde, kötü insanın ortadan kaldırılmasından çok kötülüğ̈̈ ve onu ortaya çıkaran şartları ortadan kaldırılmasının gerektiği gibi makul bir sonuca nedensellikle ulaşılabilmektedir (Arslan, 2015: 193). Zira bu bakış açısında insan seçimlerinin belli nedenlere dayandırılmış olmasıyla bu nedenlerin değiştirilmesi sonucunda istenmeyen durumların ortaya çıkmasının engellenmesinin sağlanabileceği düşünülmektedir (Arslan, 2015: 192). Bu bakımdan nedensellik ilişkisinin her zaman için pozitivist uygulamalara yol açtığı kanaati aslında yine kesin bir dışlama mantığını barındıran doğrunun kabulüne dayanmaktadır. Pozitivizme özgü nedensellikle, nedensellik karşıtlığı arasında doğruya ulaşma bağlamında farklılık gözükse de bir şeyi yanlış ya da geçersiz görme kesinliği etrafında bir benzerlik ortaya çıkmaktadır.

Bu çerçevede nedenselliğin çağdaş yaklaşımlar içinde gittikçe göz ardı edilmesi pozitivizmin katı nedenselliğinin gerekçesiyle bir doğruluk değeri taşıyor gibi gözükse de aslında böylece belirli anlamda yüzergezer ve herhangi bir ölçüte gerek duyulmayan bir bakış açısının da düşüncenin temeli oluşturulmaktadır. Oysa nedensellik en nihayetinde bir nedene gönderme yaptığ için bir kökene ve ortaya çıkış şartlarına ihtiyaç duymaktadır. Nedenselliğin dışarıda tutulduğu bir tartışma alanı tanım ve ölçütte sınırlamalar anlamına geldiği gibi anlamlandırmayı olabildiğince çoğaltma ile de açıklanabilmektedir. Tanım ve anlam üzerinde çokluk onları görelileştirmekte ve herhangi bir anlamın bir diğerine göre tercih edilebilirliğini gereksiz bir varsayım olarak görmektedir.

Bu bakış açısıyla eleştiri düzeyinde seyreden Şan'ın çokkültürlülüğe yaklaşımı da dikkat çekici hale gelmektedir. Şan'ın işaret ettiği haliyle çokkültürlülük politikası, kimi toplumlar için gereken çıkış yolunu sunabilmekle birlikte onu yeryüzündeki tüm uluslara genel geçer bir model olarak önermeyi yerinde bir siyaset olarak görmek ve 
ifade etmek zor görünmektedir (Şan, 2006: 108). Şan bu konuda şöyle demektedir: Çokkültürlülük, kendi geçmişleri en fazla iki üç yüzyıla dayanan ABD, Kanada ve Avustralya gibi daha çok dünyanın ana karalarından aldıkları göçlerle teşekkül eden ülkelere izafe edilebilir. Ancak onun, binlerce yıllık tarihsel miras taşıyan ve aynı toprakları kendilerine yurt edinerek biraradalık etiği geliştirmiş toplumlar için de aynı derecede geçerli olduğunu söylemek ikna edici olarak görünmemektedir. Çünkü çokkültürlülük, ilk bakışta farklılıklara aynı toplum içinde eşit yaşama alanı tanıma ve varlığını devam ettirme gibi güzel sözlerle ifade edilmiş olsa da bir toplum için geçerli değerlerin ve konsensüs zeminlerinin ortadan kaldırılması sorununu da taşımaktadır (Şan, 2006: 109-110). Şan'ın yaklaşımına göre bu durumda da politik anlamda çokkültürlülügün uygulanışının birçok toplumda çözülme doğurabileceği endişesi ortaya çıkmaktadır. Zira çokkültürlülüğün çeşitliliğe yaptığı vurgu, oluşmuş birlikteliklerin dağılması için bir uyarıcı işlevi görebilme olasılığını da taşımaktadır.

Gerçekte farklılıklara ait ölçüt bir yandan geçmişten beri süregelen etnik aidiyetler ile biçimlendirilirken bir yandan da kimlik ve kültür ilişkisinin hangi ölçütlere göre değerlendirileceği muğlak olarak kalmaktadır. Zira kültürel farklılık, kültür kavramının bir gruptan diğerine hangi nedenlerle değişeceğini de açıkça ortaya koyamamaktadır. Burada genel anlamda dil, ırk, din gibi daha nesnel olarak kabul edilebilecek ölçütler dikkate alınıyor gözükse de aynı dili konuşan, aynı dine mensup olan ve yine aynı ırktan gelen birçok topluluk farklılıklarıyla kendilerine tanımlamaktadırlar. Sözgelimi Arapların aynı köken ve dine sahip olmaları onlar arasındaki farklılığı önlememektedir. Benzer şekilde Kelt kökenli Avrupa etnik toplulukları da kendilerini birbirlerinden farklı olarak tanımlamaktadırlar. Latin Amerika'daki farklılıklar da Hindistan'da bir arada yaşayan çeşitli gruplardan daha fazla olmayabilmektedir. Bu haliyle farklılığın ne olduğuna ilişkin bir nesnel tanımı bulmak güçleşmektedir. Demek oluyor ki farklılığa ilişkin tanım da bir veri olarak ele alınmakta ve farklılık için öne çıkarılan vurgu ile değişim göstermektedir.

Tüm bu nedenlerden dolayı Hem Kanada'nın hem de Avustralya'nın 1970'lerde başlatmış olduğu çokkültürlülük politikası örnekleri çokkültürlülüğü hazırlayan etkenlerin üzerinde durulmasını gerektirmektedir. Görünen o ki aslında bir devlet politikası olarak tercih edilen çokkültürlüğe iten gelişmeler, tüm dünyadaki tartışmanın çıkış kaynağını oluşturmakla birlikte temeldeki bakış açısının bilimsel ve düşünsel gelişmelerin egemenliğinde olduğu ortaya çıkmaktadır.

\section{Çokkültürlülük ve Görecilik: Anlamın Çokluğu}

Çokkültürlülük kuramının ortaya çıkışında yirminci yüzyılda fizik bilimi içinde gelişen göreliliğin, tüm sosyal bilimlerde olduğu gibi, etkisini dikkate almakta fayda vardır. Zira fizikteki görelilik konusu çokkültürlülüğün desteklenmesine imkân sağlamıştır. Bu konuda Fay şöyle demektedir: “Görecilik çokkültürrcülüğü teşvik ediyor... çokkültürcülük, çağdaş dünyada yaşamsal bir şeye, birbirlerinden önemli biçimde farklı olan insanların birbirleriyle temasta olduklarına ve birbirleriyle iş yapmaları gerektiğine işaret ediyor" (Fay, 2012: 15). Fay, bu durumun sevindirici olmadığını da belirtmektedir. Ona göre bütün çokkültürcüler, kültürel ve toplumsal 
farklılığı anlamaya ve bununla yaşamaya vurgu yapsa da bu tartışmanın içinde çeşitli insan grupları arasında farklılığın yüceltilmesini içeren yaygın bir versiyon da bulunmaktadır (Fay, 2012: 15.) Bu eleştirisinin yanında Fay, çokkültürlülüğün işleyiş biçimi üzerinde durarak onun perspektifini de tarif etmektedir:

Çokkültürlü duyarlığın ayırt edici özelliklerinden biri, kişinin ötekilerin kendisinden ve kendi grubundakilerden farklı davrandıklarının bilincinde olmasıdır. Herhangi bir konuşma edimiyle, bir jestle ya da pratikle sizin kastettiğiniz şeyin, ötekilerin de bunlarla kastettikleriyle aynı olduğunu varsayamazsınız. Bunun soncu olarak, çokkültürcülüğün ana kurallarından biri şudur: Ötekilerin belli bir davranışla, aynı davranışı siz yaptığınızda kastettiğiniz şeyi kastettiğini düşünmeyin ve daima, bu davranışın anlamının, ilk bakışta göründüğünden farklı olabileceğini varsayarak, "Bu ne anlama geliyor?" diye sorun. Anlama ilişkin sorular çokkültürlü deneyimin can damarlarından biridir (Fay, 2012: 181).

Fay'in işaret ettiği anlama ilişkin sorular, anlam ve eylem arasındaki bağı öne çıkarmaktadır. Elbette davranışların anlamı vardır ancak anlamın sadece davranışlardan çıkarılması gerekliliği aynı zamanda davranışların sabitlenmesi gerekliliğine de işaret etmektedir. Bu doğrultuda davranış, anlam koymada belirleyici ölçüt haline gelmektedir. Anlam ve eylem arasındaki ilişkinin mutlaklaştırılmasının ortaya çıtığı bu düşünce yirminci yüzyılın ikinci yarısında özellikle Deleuze ve Guttari'nin görüşlerinde felsefi bir zeminde yeniden kurgulanmıştır. Tartışmanın felsefi kökeninde daha ziyade Deleuze tek başına kaleme aldığı eserleriyle dikkat çekse de, farklı bir toplumsal biçimlenme ya da toplumsallık karşıtlığı bağlamında Deleuze ve Guattari'nin ortak yazdıkları kitaplar genel çerçeveyi somutlaştırarak şekillenmektedir. Deleuze ve Guattari'nin öne sürdükleri görüşler ile çokkültürlülügüun düşünsel altyapısı karşılaştırıldığında Fay'in dediği gibi farklılıkların yüceltilmesi bağlamında bir paralellik ortaya çıkmaktadır. Aşağıda göreceğimiz üzere herhangi bir merkeze bağlanmayan ve böylece sabit kalarak, birliğe işaret etmeden oluşturulan bir anlam biçimi, Deleuze ve Guattari 'nin düşüncesinin özünde yer almaktadır. Anlam üzerine ortaya konan düşünce özellikle Deleuze'ün yazdığı 'Anlamın Mantığı' adlı eserde şekillenmektedir.

Deleuze'e göre Platon temsilin yaygınlaşmasına yol açan idealar teorisiyle yola çıkmaktadır (Deleuze, 2014: 334). Her ne kadar o, Platon için bu tespiti yapsa da kendisi de idealara karşı geliştirdiği fikirler ile düşüncesini kurmaya başlar. Dolayısıyla o da Platon'la aynı yerden başlamaktadır. Ancak onun başlangıç noktası Platon'a ve dolayısıyla da idealizme karşı çıkmaktır.

Platon'dan Hegel'e kadar süren idealizme karşı çıkan Deleuze, idealizm yerine ampirizmi tercih etmektedir. Fakat Deleuze'deki ampirizm, gerçekte alışılagelmiş olandan farklıdır. Zira "ampirizmden esinlenen Deleuze mantığ1 bir 'yüklemleme ve doğruluk' mantığı değil bir 'anlam ve olay mantı̆̆ı' dır" (Rajchman, 2013: 55-56). Kaldı ki Deleuze'e göre sadece ampirizm, görünür olanın deneyimsel boyutlarını idealara düşmeksizin aşmayı başarmaktadır (Deleuze, 2015: 38).

Deleuze'ün ampirizminde olay ve olayın gerçekleşmesi, yaklaşımında anlamın ne olduğunu açıklamaktadır. Zira onun görüşünde olay yalnızca, saf ifade edilen olarak ele alınmaktadır. Yani, olay burada başa gelen herhangi bir kaza gibi bir şey 
değildir (Deleuze, 2015: 169). Burada olay Deleuze'e göre nüfuz edilemez bir cisimsizliktir. Olay cisimlere fiziksel bir nitelik olarak değil sadece cisimsiz bir nitelik olarak atfedilmektedir. Bu atfetme sırasında olay, önermede var olmaktadır ama bu var olma da bir fiilde kuşatılmış olan ifade edilebilir ya da ifade edilen olarak var olmaktadır (Deleuze, 2015: 204). Dolayısıyla artık olay oluşla, oluş ise dille aynı kapsama sahiptir (Deleuze, 2015: 25).

Deleuze için olaylar birbirlerinin nedeni olamazlar ama birbirleriyle yarı nedensellik ilişkisine girebilmektedirler (Deleuze, 2015: 51). Çünkü olay tek bir yönde değil aynı anda iki yönde birden gitmektedir. Bu çifte güzergâhla olay, özneyi parçalamakta ve paradoks oluşmaktadır (Deleuze, 2015: 19). İşte bu paradoks Deleuze için negatif bir durum değildir. Zaten o, "tekil, biçimsiz, mitleri, 'çoğunluk' modelleri ya da tarihleri olmayan, henüz icat edilmemiş bir 'çokluğa' çağrı yapar" (Rajhman, 2013: 36). Bir olayın anlamının ne olduğunu sormaya gerek yoktur. Olay anlamın ta kendisidir (Deleuze, 2015: 39). Dolayısıyla anlam aynı zamanda sürekli bir oluş halidir. Olayın fiille birlikte oluşla açıklandığı bu düşünce biçiminde fiilin sürekli eylem oluşu anlamın da sürekliliğini gerektirmektedir. Fiildeki akış anlamın da akışıdır artık. Ancak akışın tek nedenli olmayışı onun ya da bir nedene bağlanmayışı bir belirsizlik ve paradoks oluşturmaktadır. Bu paradoks ise çokluğun kendisidir.

Bu durumda da sınırsız oluş da olayın kendisi haline gelmektedir (Deleuze, 2015: 24). Sınırsızlık ve paradoks içinde bir sabit ya da değişmez anlam üretmek hem imkânsız olmaktadır. Deleuze'e göre aslında sabit bir anlam da gerekmez. Zira onun yaklaşımında "anlam olumlamanın da olumsuzlamanın da askıya alınmasına yol açar" (Deleuze, 2015: 49). Hem olumlamanın hem de olumsuzlamanın askıya alınması doğal olarak anlama sabitlik yüklemektedir. Unutmamak gerekir ki sabitliğin varlığı aynı zamanda onun bir merkez olarak görülmesini doğuracaktır.

Herhangi bir köke ya da merkeze dayanmayan oluşumun adı 'Bin Yayla'da yaylalarla ilişkili olan rizomla açıklanmaktadır. Onlar yaylayı rizomu biçimlendiren ve yayan ama derinliği olmayan çokluklar olarak adlandırmaktadırlar. Bu çokluklar diğer çokluklarla bağlantılıdır. Dolayısıyla her yayla, herhangi bir yerden başlayan bir şekilde ve her biri diğer çokluklarla ilişkili olan yayladır (Deleuze ve Guattari, 2014: 23).

Deleuze anlamın çokluğunu olayı, bizzat somut varlık alanıyla açıklayarak oluşturmaktadır. Burada oluş, nispeten metafizik bir varlık olan olayın, herhangi bir somut varlıkla fiil olarak buluşmasıyla mümkün olmaktadır. Böylece idealara ihtiyaç duymadan oluşun bir akış haliyle varlık kazandığı gözlemlenmektedir. Bir akış halinde gerçekleşen oluş dizilimi, görünenler ve deneyimlenebilenler arasında farklılığı meydana getirmektedir. Farklılık bir sabit referansa atfen değil, deneyimden türeyen değişmelere ya da değişikliklere göre oluşturulmaktadır. Yüzeyde dönen somut ve görünür farklılıklar, farkın temeline yerleştirilmektedir.

Deleuze'ün bir başına öne sürdüğü oluş ve Guattari ile birlikte geliştirdikleri rizom düşüncesi, bu bağlamda sabit bir referansı gerektirmeden bir dizilim göstermektedir. Herhangi bir köke dayanmayan bu dizilimlerdeki çokluk 'bir'den 
türetilmiş çokluğu ifade etmez. O bir çokluktur. Fakat yüzergezer köksüz bir çokluk olarak vardır. Bu haliyle çokluk onun düşüncesinde bizatihi çokluk olarak var olmaktadır. Dolayısıyla onun 'bir'liğe döndürülme ya da gönderilme olasılığı dahi olmamaktadir.

$\mathrm{Bu}$ düşünce çerçevesinde farklılıklar da bir referansa bağlanamamaktadır. Farklılık 'bir'den türemediği için 'bir'e döndürülemez de. Farklılığa yüklenen anlam, bir düşünce ya da inanç yahut hissiyattan ziyade yaşayışa ilişkin farklılıklardan devşirilecek ve zaten verili olarak var kabul edilecektir. Bu bağlamda bir aidiyet hissi ya da inancı söz konusu olamayacağına göre veyahut da bir inanca tabi olmak farklılık ve benzerlik için ölçüt olmayacă̆ına göre tartışma alanına dahi girmemektedir.

\section{SONUÇ}

Görünen o ki çokkültürlülük, modernizmin homojen toplum düşüncesi dışında yer alarak heterojenliği öne çıkarmaktadır. Fakat çokkültürlülük bu heterojenlikle birlikte, siyasal bütünlüğü ve merkeziliği koruyarak siyasal düşünceden ayrışmış yaşam pratikleri etrafında çeşitliliğe vurgu yapmaktadır. Bu durum, hem Kanada hem de Avustralya örneğinde açık olarak görülmektedir. Bununla birlikte yaşam pratiklerindeki farklılığa ilişkin tanım ve anlamlandırma düzeyinde bir muğlaklık mevcuttur. Farklılığı belirleyen ölçütlerin ne olduğu açı değildir.

Anlamlandırmanın ve dolayısıyla anlamın çokluğu ise bizzat geleneksel düşünceden farklı olarak yirminci yüzyılda artan bir ivme ile şekillenmeye başlamış ve son olarak Deleuze ve Guattari'nin yaklaşımıyla ortaya konmuştur. Bu düşünce, Deleuze ve Guattari'de Palton'dan Hegel'e uzanan idealizm karşıtlı̆̆ örneğinde köksüz ve bağsız çokluk haline gelmiştir.

Deleuze ve Guattari'nin yaklaşımında düşüncenin temeline yerleştirilmek istenen çokluk, benzerlik yerine farklılığın öne çıkarılmasını önemseyen bir bakış açısını içermektedir. Çokkültürlülük de kendini farklı kültürlerle tanımlama ve ifade etme aracı olarak ortaya konmakta ve ona bu doğrultuda bir anlam yüklenmektedir. Yüklenilen anlam benzerlik yerine farklılığı referans aldığı için çok çeşitliliğe vurguyu güçlendirmektedir. Bu bakımdan da ülke içindeki toplumsal birlikteliklere verilen ve yüklenen anlamda çokkültürlülük öncesi ve çokkültürlülük sonrasında farklılaşmanın varlığ1 görülmektedir. Toplumsallığa yüklenen anlam çokkültürlülük öncesinde benzerlik ve bütünlük çerçevesinde konulurken çokkültürlülük sonrasında toplumsallık örüntüleri arasındaki farklılıkları öne çıkaracak bir bakış açısıyla konulmaktadır. Bu ayrım düşünsel kökenlerini idealizm ve materyalizm karşıtlığında bulmaktadır. Birincisinde derin bir köke ve sabit bağa ihtiyaç duyularak 'bir'lik oluşturulurken diğerinde 'bir'in ya da 'bütün'ün tasavvurla oluşturulduğu görüşüyle her somut oluşumun farklılıkla açıklanmaktadır. $\mathrm{Bu}$ durum çokkültürlülük kavramının anlamın çokluğu üzerinde yükseldiğini ortaya koymaktadır. Zira çokkültürlülükle birlikte sonuçta düşünsel düzeyde kültür olarak görülebilecek yaşamsal pratiklerde bir merkeze ya da merkezi kültür biçimlenmesine duyulan ihtiyaç önemsizleştirilmektedir. 


\section{KAYNAKÇA}

Arslan, A, (2015) Felsefeye Giriş, Ankara: Adres Yayınları.

Bryson, B. (2005) Making Multiculturalism Boundaries and Meaning. Stanford California: Stanford University Press.

Deleuze, G. (2015) Anlamın Mantığı (H. Yücefer Çev.). İstanbul: Norgunk Yayıncllık.

Deleuze, G. (2014) Difference and Repetition (P. Patton Trans.). London, Bloomsbury Academic.

Deleuze G. and Guattari F. (2014) A Thousand Plateaus Capitalism and Schizophrenia (B. Massumi Trans.). London: Bloomsbury Publishing Plc.

Doytcheva, M. (2009) Çokkültürlülük, (T. Akıncılar Onmuş Çev.), İstanbul: İletişim Yayınları.

Fay, B. (2012) Çă̆daş Sosyal Bilimler Felsefesi (İ. Türkmen Çev.). İstanbul: Ayrıntı yayınları. İst., 2012.

Giddens, A. and Sutton, P. W. (2013) Sociology. 7. Edition. Cambridge: Polity Press.

Heywood, A. Siyaset (2007) (B. Kalkan editörlüğünde, B. B. Özipek, B. Şahin vd. Çev.). Ankara: Adres Yayınları.

Jupp, J. and Clyne, M. (2011) Introduction - Multiculturalism and Integration A Harmonious Relationship (M. Clyne and J. Jupp Ed.) Canberra: The Australian University Press.

Kymlicka, W. (2006) Çă̆daş Siyaset Felsefesine Giriş, (Çev.: E. Kılıç Çev.). İstanbul: İstanbul Bilgi Üniversitesi Yayınları.

Parekh, B. (2000) Rethinking Multiculturalism Cultural Diversity and Political Theory. London: Macmillan Press Ltd.

Rajchman, J., (2013) Deleuze Bağlantıları.(B. Şannan Çev.). İstanbul: Bağlam Yayıncılık.

Roach, N., Alwis, R. and Others. (April 1999) Australian Multiculturalism For A New Century: Towards Inclusiviness. Australia: A Report By National Advisory Council.

Say, Ö., (2013), 21. Yüzyılda Ulus Çokkültürlülük ve Etnisite, İstanbul, Kaknüs Yayınları.

Şan, M. K. (Aralık 2005-Haziran 2006) Farklılık ve Çokkültürlülük Siyasetleri Üstüne Bir Deneme. Milel ve Nihal Dergisi, 5 (1-2): 67-114.

Taylor, C. (2010) Tanınma Politikası, Çokkültürcülük. Amy Gutman Haz.)., Çev.: Y. Salman Çev.). İstanbul: 2010. 